\title{
Workforce Factors and Banking Performance
}

\author{
Fanny Soewignyo, Tonny Irianto Soewignyo \\ Universitas Klabat, Airmadidi-Manado, Indonesia
}

\begin{abstract}
This paper examined the workforce factors to predict Indonesian banking performance measured by per employee metrics. Using purposive sampling, 31 banks listed on Indonesia Stock Exchange (IDX) in 2012 were utilized. Five workforce factors were employed as independent variables and banking performance as dependent variable was measured using revenue per employee and market capitalization per employee. Data needed to measure the five workforce factors as well as revenue are available in the annual reports. However, market capitalization data are available in the IDX statistics. Five hypotheses were tested using multiple regression analysis. The authors concluded on two things. Firstly, the larger the number of employees, the worsen revenue per employee and market capitalization per employee. Secondly, higher remuneration for directors and commissioners induced better performance, as measured by the two indicators. This study is limited in so far as it considers banking companies listed on IDX only and conducted for only one financial year. However, the result could give better understanding of performance and its drivers and lead to managerial practices that can improve banking performance. This study also provides relevant information to scholars, policy makers, investors, and other stakeholders as a basic reference and guide to analyze the banking performance.
\end{abstract}

Keywords: banking performance, market capitalization per employee, revenue per employee, workforce factors

As a knowledge intensive industry, banking industry faces the difficulty of limited source of suitable talent within their businesses. Worldwide, the financial services industry is facing a scarcity of talent (PwC, 2012a). High turnover and high recruitment demand with large salary increase are still at rise. Thus far, compensation and benefit become the focus for many corporations (Kelly Services, Inc., 2013). Many companies in the finance industry have asserted that their employees are of vital competitive advantage (Groysberg, 2011).

Being majorly dependent on skilled labor, the finance industry is always in need of talent (Kneer, 2013). Moreover, excellent performance of a number of biggest and the most successful companies over the past decade indicates that financial performance increasingly derives from returns on talent. In a competitive environment where talented employees create intangible assets, return on talent is powerful to offer the larger part of new wealth (Bryan, 2007). Hence, the purpose of this study was to investigate the workforce factors contribute to Indonesian banking performance.

Strong institutions cannot be created instantly, more research effort should be done. More specifically, based on a thorough review, no prior study has, theoretically or empirically, examined the workforce factors to

Corresponding author: Fanny Soewignyo, Ph.D. in commerce, senior lecturer, Universitas Klabat, Airmadidi, Minahasa Utara, Sulawesi Utara, Indonesia; research fields: accounting, finance, and corporate performance. E-mail: fanny_soewignyo@yahoo.com.

Tonny Irianto Soewignyo, Ph.D. in commerce, senior lecturer, Universitas Klabat, Airmadidi, Minahasa Utara, Sulawesi Utara, Indonesia; research fields: entrepreneurial, finance, marketing, and quality management. E-mail: tonnysoewignyo@unklab.ac.id. 
predict Indonesian banking performance measured by per employee metrics. Per employee metrics is applied in measuring banking performance for the reason that they can assess quality as stated by Morgan Stanley (2011) and furthermore, they can give a performance score to each employee.

The excellent performance of employees in one company does not guarantee the same level of performance in the other (Groysberg, 2011). It is observed that gross domestic product (GDP) is increasingly based on the knowledge, creativity, and ability of workers to innovate (Shapiro, 2006). As can be seen in modern industries, talent, innovation, and growth are connected and indicated by greater workforce skills and technology intensities. This relationship is forecasted to be strengthened by more than $70 \%$ by 2020 (Dirks, Gurdgiev, \& Keeling, 2010). Despite high level of unemployment and oversupply of job seekers, some companies face shortage of skilled and talented workforce. Even a large increase in wages will not necessarily lead to many new people ready to fill the jobs. Therefore, according to Groysberg (2011), fair payment to employees is important so as to retain talent. Bryan (2007) asserted that nowadays, intensive talent drives the creation of wealth and must be measured accurately by company management. It is real that so many business leaders change talent strategies in order to solve their problems of skill shortages which could have significant impacts on corporate growth. As customers' needs change rapidly, the workforces and talent needs are changing as well (PwC, 2012b).

This study particularly focuses on the five workforce factors (board of commissioners size, board of directors size, audit committee size, total number of employees, board of commissioners, and board of directors remuneration) and two performance measures (revenue per employee and market capitalization per employee):

(1) Board of commissioners size. According to Indonesian board of commissioners principles, the size of the board of commissioners must be sufficient to fit the complexity of the business by taking into account the effectiveness of decision-making. The board shall function and be responsible for overseeing and providing advice to the board of directors and ensuring that the company implements good corporate governance. However, the board is prohibited to participate in making operational decisions. Each member, including the chairman, has equal position. The duty of the Chairman of the Board of Commissioners is to coordinate the activities of the board of commissioners (National Committee on Governance, 2006);

(2) Board of directors size. As stated by National Committee on Governance (2006), the composition of board of directors must be of sufficient size that suits the complexity of the business by taking into account the effectiveness of decision-making. In addition, Č. Ljubojević and G. Ljubojević (2008) argued that board size may influence the dynamics in board functions. For instance, a large and diverse board of directors may improve board performance in terms of knowledge and talents. In contrast, this form of board would likely face group dynamics dilemma, which in turn makes the board less effective. Smaller boards are more efficient compared with boards with more members as it is easier to attain agreements on decision-making (Lublin, 2014);

(3) Audit committee size. An audit committee is assigned to give an independent professional advice to the board of commissioners upon the statement or other matters, which are submitted by the board of directors to the board of commissioners, and identify the matters which need the board of commissioners' attention. An independent committee is the one that consists entirely of outside and independent directors (Rebeiz \& Salameh, 2006). The audit committee is at least comprised of three persons, one of whom will be the independent commissioner of the listed company who is also the chairman of the audit committee, while the other members are the external parties who are independent, at least one of whom must be an expert in accounting and/or finance (Capital Market Supervisory Agency, 2004; Jakarta Stock Exchange Inc., 2004). Experience shows that 
an audit committee is likely to function most effectively with small membership of three to six people (Wallace \& Zinkin, 2005);

(4) Total number of employees. As asserted by Bryan (2007), annual reports are filled with information regarding capital utilization but present insufficient information about the number of employees. Therefore, according to Bapepam and LK Rulebook (2006), annual report of a public company as an important source of information for shareholders and general public in making investment decision is required to discuss the number of employees as well;

(5) Board of commissioners and board of directors remuneration. Board of commissioners and board of directors remuneration is an important information regarding the implementation of good corporate governance in Indonesia, which are required to be disclosed in the annual report of publicly listed company (National Committee on Governance, 2006). The principles of corporate governance indicate that the remuneration of commissioners and directors is an important aspect for effective implementation of corporate governance (Oviantari, 2011). According to Talha, Sallehhuddin, and Masuod (2009), remuneration of directors (executive and non-executive) which includes the basic salary and other monetary or non-monetary benefits received during their tenure, should be included in the corporate governance process;

(6) Revenue per employee. Financial performance of a service-oriented firm according to Reeve, Warren, and Duchac (2012) can be assessed using revenue per employee. It measures the efficiency of a firm in generating revenues. The higher revenue per employee indicates efficiency of the firm in generating revenue from its employees. It is important to compare revenue per employee within an industry and over time. Moreover, according to ACA International (2010), revenue per employee is measured as the ratio of revenue to the number of employees required at that level of revenue. When making a comparison between two companies, the company with the higher value for revenues per employee would be considered more efficient or productive. Revenue per employee can be used to track the impact of staffing processes on productivity. As staff are added, the resulting increase or decrease in revenue per employee could help in measuring the changes in output. This concept supports D' Amico (2004) who asserted that revenue per employee is a commonly used measure of management efficiency. It provides an interesting view of how well a company runs. It shows how a company is doing against its competitor and the best run companies have high revenue per employee;

(7) Market capitalization per employee. Market capitalization states the value of a company in the market, that is, for how much the company can be sold in the market. It is a significant means to measure the ability of the market to mobilize capital and to measure the firm size. It indicates the value of a firm by multiplying the number of outstanding stock with the current stock price. Market capitalization is compared with the book value by analysts to assess company's future prospects, whilst institutional investors analyze it as an investment criterion (Yasmin \& Yusuf, 2008). It can be used to get a picture of the company's value in the market place. According to Nash (2006), the smartest companies are those where people are engaged, productive, and forward thinking. The stock buying choices of investors create market value of a company and in effect, judging the value of employees. Therefore, Bryan (2007) asserted that market capitalization can be regarded as a function of return on talent. Moreover, to give a performance score to each employee, this study measures market performance by utilizing market capitalization per employee.

The remainder of the paper is organized as follows. The next part briefly reviews the literature on the relationship of workforce and company performance. The third part discusses the methods and the fourth part focuses on the results. The final part is the discussion, which states the outcomes of the research. 


\section{Workforce and Company Performance}

Talent in the workforce continually provides economic benefits at many levels, generates wealth and hence needs to be measured more accurately by business executives (Bryan, 2007; Society for Human Resource Management, 2012). In today's economy, business performance is critically driven by talent. Talent has become the key competitive factor of every business and the incremental value of talented people keep on growing whilst the supply lags behind the demand (Mariner7.com, n.d.). Therefore, every organization must make sure that they have the talent needed to achieve the expected performance since talented people could be available but not always in the position where they are needed. The right talent could be somewhere in the world (Craig, Thomas, Hou, \& Mathur, 2011). The collaboration of talented people in a company creates intangible value and subsequently increased revenues.

By utilizing sample firms listed on New Zealand Stock Exchange over a four year period from 2004 to 2007, Bathula (2008) found that board size is positively associated with firm performance and frequency of board of directors meetings negatively affect firm performance. Likewise, based on a randomly selected sample of 75 companies listed on Bursa Malaysia, Abidin, Kamal, and Jusoff (2009) found that board size has a positive impact on firm performance. On the other side, using a sample of 93 non-financial firms listed on Dhaka Stock Exchange in 2006, Rouf (2011) found that there is no significant relationship between board size and firm value measured by return on equity and return of assets as dependent variables. Angaye, Gwilliam, Marnet, and Thomas (2009) employed board structure as proxy of corporate governance measured by board size, board composition, ownership structure, leadership structure and duality, board diversity, and CEO (chief executive officer) nationality status. The empirical findings do not generally indicate any significant associations between the investigated board size and corporate performance measured by profitability as well as other performance measures. Van Ness, Miesing, and Kang (2010) found board size is positively related to revenue growth. This result implied that larger boards tend to increase revenues.

The management of a limited liability company in Indonesia adopts a two board system, namely the board of commissioners and the board of directors. Each of which has a clear authority and responsibility based on their respective functions as mandated by the articles of association and laws and regulations. Yet, they both have the responsibility to maintain the company sustainability in the long term and have the same perception regarding the company's vision, mission, and values. The board of commissioners performs the supervisory and advisory roles, and the board of directors performs the executive role (National Committee on Governance, 2006). Responding to the different findings related to board structure and the two tier board system in Indonesia, the following research hypotheses are set:

H1: Companies with a greater number of board of commissioners members will have greater revenue per employee and market capitalization per employee.

Total number of board of commissioners members was used to measure board of commissioners size. Total revenue divided by total number of employees was used to measure revenue per employee, and market capitalization divided by total number of employee was used to measure market capitalization per employee.

H2: Companies with a greater number of board of directors members will have greater revenue per employee and market capitalization per employee.

Total number of board of directors members was used to measure board of directors size. 
H3: Companies with greater number of audit committee members will have greater revenue per employee and market capitalization per employee.

Chhinzer and Ghatehorde (2009) analyzed academic research to investigate the relationship between human resources metrics (e.g., headcount, salaries, recruitment) and organizational financial performance (e.g., revenue, costs, profit). They concluded that most firms decrease their workforce through layoffs or downsizing to improve financial performance and rarely react to poor financial performance by increasing its workforce. On the contrary, regardless of their performance or cost related to workforce, companies do not downsize when doing well financially. Based on these conclusions, the following hypothesis is set:

H4: Companies with greater number of employees will have greater revenue per employee and market capitalization per employee.

Total number of permanent and non-permanent employees reported in 2012 annual report was used to measure the number of employees.

The study of Oviantari (2011) investigated the relationship between Indonesian board of commissioners and board of directors' remuneration and firm performance using a sample of 100 listed companies throughout the period of 2008-2009. The study found that the return on assets and the remuneration of commissioners and directors show a negative direction. It could be argued that the negative direction is significant because the observation period is the period of global financial crisis. Therefore, even if the direction is negative, shareholders keep on increasing the remuneration to motivate management to maintain the business processes in a going-concern condition. The study also found that sales positively affect remuneration. On the contrary, the relationship between variable remuneration and earnings per share is not significant. In fact, the principles of corporate governance require that directors' remuneration should be linked to corporate performance. In line with that result, using panel data for the period 1992-2005, Doucouliagos, Haman, and Askary (2007) explored the relationship between board of director's pay and performance of Australian banking. The results indicate that Australian directors' pay does not relate to performance with a one year lag. However, with a two year lag, total directors' pay had robust positive association with earnings per share (EPS), as well as with return on equity (ROE). Likewise, the study of Ghosh and Aggarwal (2011) in India focused on the effectiveness of the boards to the firm's performance with the financial data of 25 companies for seven years. They found that directors' remuneration does not have any significant relationship with firm's profitability. Based on these findings and the requirement of corporate governance principles, the following hypothesis is set:

H5: Companies with greater board of commissioners and board of directors remuneration will have greater revenue per employee and market capitalization per employee.

Board of commissioners and directors remuneration was measured by total compensation for commissioners and directors such as salaries, allowances, bonuses, and other facilities. The reason for utilizing total remuneration amount for both commissioners and directors is because some companies do not report the remuneration for commissioners and directors separately.

\section{Research Method}

\section{Population and Sample}

The listed banking companies in general offer an ideal area of workforce factors research, because: (1) there are reliable data available in the form of published annual reports; (2) the business nature of banking sector is always in need of talent that is heavily relied on skilled labor; and (3) the participants of stock 
exchange are deeply concerned with the corporate governance and performance. Not all of the 32 listed banks were used for this study. One company was excluded from the study due to negative profit which yielded a final sample of 31 companies.

\section{Data Collection}

This study used secondary data: annual reports of the listed banks and Indonesia Stock Exchange (IDX) statistics which are available on the IDX website. Campbell and Abdul Rahman (2010) noted that the company has total editorial control over the annual report and it is usually the most widely issued of all public documents produced by the company. There are two dependent variables used in this study to measure banking performance that focus on per employee metrics consisting of logarithm of revenue per employee and logarithm of market capitalization per employee. Five workforce factors as independent variables were employed. Data needed to measure the workforce factors as well as revenue are available in the annual reports. However, market capitalization data are available in the IDX statistics.

\section{Statistical Analysis}

The multiple regression analysis was performed to test the influence of independent variables to dependent variables. The regression models are presented below:

1. Workforce factors predict revenue per employee.

$$
\operatorname{LogRev}=\beta_{0}+\beta_{1} \operatorname{LogBOCs}+\beta_{2} \operatorname{LogBODs}+\beta_{3} \log \mathrm{ACs}+\beta_{4} \log \mathrm{TNE}+\beta_{5} \operatorname{LogBRem}+\varepsilon
$$

2. Workforce factors predict market capitalization per employee.

$$
\operatorname{LogMark}=\beta_{0}+\beta_{1} \operatorname{LogBOCs}+\beta_{2} \operatorname{LogBODs}+\beta_{3} \log \mathrm{ACs}+\beta_{4} \log \mathrm{TNE}+\beta_{5} \operatorname{LogBRem}+\varepsilon
$$
Where:

$\operatorname{LogRev}=$ logarithm of revenue per employee;

LogMark = logarithm of market capitalization per employee;

LogBOCs = logarithm of board of commissioners size;

LogBODs = logarithm of board of directors size;

LogACs $=$ logarithm of audit committee size;

$\log \mathrm{TNE}=$ logarithm of total number of employees;

LogBRem $=$ logarithm of board of directors and board of commissioners remuneration;

$\beta_{0}=$ intercept coefficient;

$\beta_{1,} \beta_{2,} \beta_{3,}, \beta_{4}, \beta_{5}=$ coefficient for each of the independent variables;

$\varepsilon=$ error term.

Linearity assumption was verified through examination of scatter plots of residuals that indicates linear relationship between the independent variables and the dependent variable. Normal probability plots have given evidence to the normality of data used. The plots appear as a straight line all the way through. These results supported by Chan (2003) that small sample sizes of $n<30$ are always assumed as not normal and moderate sample size is between 30 and 100. With these reasons, the sample size of 31 is assumed as normal. Multicollinearity between the independent variables was checked with variance inflation factors (VIFs). The VIF values indicate that multicollinearity is not a problem for this analysis as the VIF values are below the recommended cutoff of 10 . The plots of revenue per employee and market capitalization per employee have no pattern, which implies that no heteroscedasticity caused by these variables. As stated by Gupta (2000), heteroscedasticity implies that the variances of the residuals are not constant. 


\section{Results}

Table 1 presents the results of multiple regression analysis. The first regression model of the study with revenue per employee as dependent variable shows the calculated $F$-statistic is 3.508 and the significant $F$ is at $p$-value of 0.015 . This result reveals that the overall model is significant with the adjusted $R^{2}$ of $29.5 \%$. The second regression model with market capitalization per employee as dependent variable shows the calculated $F$-statistic is 5.273 and the significant $F$ is at $p$-value of 0.002 . This result also suggests that the overall model is significant with the adjusted $R^{2}$ of $41.6 \%$. Each hypothesized workforce factor is examined further below.

The empirical results show that $\mathrm{H} 1, \mathrm{H} 2$, and $\mathrm{H} 3$ are not supported with $p$-value $>0.05$. Hence, board of commissioners size, board of directors size, and audit committee size do not have a significant influence on either revenue per employee or market capitalization per employee. $\mathrm{H} 4$ predicts companies with greater number of employees will have a greater revenue per employee and market capitalization per employee. The results show a negative and statistically significant influence of total number of employees toward revenue per employee $(\beta=-0.519, p=0.005)$, and market capitalization per employee $(\beta=-0.621, p=0.013)$. H5 predicts companies with greater board of commissioners and board of directors remuneration will have a greater revenue per employee and market capitalization per employee. The empirical results show that the coefficient for board of commissioners and board of directors remuneration is positive and statistically significant with revenue per employee $(\beta=0.747, p=0.003)$, and market capitalization per employee $(\beta=0.902, p=0.007)$. Thus, hypothesis H5 is fully supported.

Table 1

Results of Multiple Regression Analysis for Each Performance Measure (H1-H5)

\begin{tabular}{lll}
\hline & $\begin{array}{l}\text { Revenue } \\
\text { per employee }\end{array}$ & $\begin{array}{l}\text { Market capitalization } \\
\text { per employee }\end{array}$ \\
\hline Variables (with hypothesized relationships in parentheses) & $\begin{array}{l}\left.\text { Unstandardized } \beta \text { (p-value }^{*}\right) \\
1.303(0.052)\end{array}$ & $\begin{array}{l}\text { Unstandardized } \beta\left(\mathrm{p} \text {-value }^{*}\right) \\
1.065(0.237)\end{array}$ \\
(Constant) & & \\
\hline Hypotheses: & $-0.033(0.373)$ & $0.013(0.801)$ \\
\hline H1: Board of commissioners size $(+)$ & $-0.003(0.939)$ & $0.025(0.659)$ \\
H2: Board of directors size $(+)$ & $0.054(0.287)$ & $0.010(0.890)$ \\
H3: Audit committee size $(+)$ & $-0.519(0.005)$ & $-0.621(0.013)$ \\
H4: Total number of employees $(+)$ & $0.747(0.003)$ & $0.902(0.007)$ \\
H5: Board of commissioners and directors remuneration $(+)$ & 0.412 & 0.513 \\
$R^{2}=$ & 0.295 & 0.416 \\
Adj. $R^{2}=$ & 3.508 & 5.273 \\
$F$-value $=$ & 0.015 & 0.002 \\
Prob. $(F)=$ & 31 & 31 \\
No. of companies/observations $=$ & LogRev & LogMark \\
Dependent variable & &
\end{tabular}

Notes. Predictors: (Constant), LogBOCs, LogBODs, LogACs, LogTNE, LogBRem; ${ }^{*}$ significant at the 0.05 level.

\section{Discussion}

Empirical data from this study provide support for the importance of workforce factors in determining Indonesian banking sector performance. The result reveals that the overall model is significant that $29.5 \%$ of the variance in revenue per employee can be explained by the five workforce factor predictor variables and 
$41.6 \%$ of the variance in market capitalization per employee can be explained by the five workforce factor predictor variables.

The results have several implications for banking sector employers, regulators, board of commissioners, board of directors, and managers. First, board of commissioners size, board of directors size, and audit committee size do not have a significant influence on either revenue per employee or market capitalization per employee. This finding should be particularly informative to regulators and board of commissioners in their evaluation of the desirable board and audit committee size. The results support the view in the literature that there is no significant relationship between board size and corporate performance (Angaye et al., 2009; Rouf, 2011) and as concluded by Craig et al. (2011) that every organization must make sure they have the right talent needed to achieve the expected performance since talented people could be available but not always in the right position where they are needed. However, these results were not in line with KPMG, LLP (2010) that stated the collaboration of talented people in a company creates intangible values and consequently increases revenues. Second, the results indicate that banking sector performance measured by revenue per employee and market capitalization per employee tends to decrease when the number of employees increased. This finding is in agreement with Chhinzer and Ghatehorde's (2009) that most firms decrease their workforce to improve financial performance. Third, when the board of commissioners and board of directors remuneration increased, revenue per employee and market capitalization per employee are likely to increase. Although, these results differ from those studies of Doucouliagos et al. (2007), Ghosh and Aggarwal (2011), and Oviantari (2011), however, they are consistent with the principles of corporate governance that directors remuneration should be linked to corporate performance (Oviantari, 2011).

The findings indicate that directors and managers should pay particular attention to the number of employees, as the greater the number of employees, the lesser the banking performance. Furthermore, employers should understand that increasing the board of commissioners and board of directors remuneration is needed to improve banking performance. Individuals responsible for developing a company's board of commissioners and board of directors remuneration should be mindful of its significance. Finally, these findings provide several contributions to accounting, finance, and management academic research. Prior studies have examined the influence of workforce factors on firm performance, however, none of those studies has, theoretically or empirically, examined the five factors simultaneously to predict firm performance measured by the two per employee metrics. The findings obtained are important to be used by the banking sector to give better understanding of performance and its drivers and lead to managerial practices that can improve company performance of this significant sector of economic activity. This study also provides relevant information to scholars, policy makers, investors, and other stakeholders as a basic reference and guide to analyze the banking performance.

This study is limited in so far as it considers banking sector listed on IDX only and was conducted for only one financial year. To support the robustness of the conclusions to confirm the applicability of the findings of this study, future research can build on this work by investigating data from other industries, other markets, and longitudinal data analysis to better understand which workforce factors matter and when they matter most. Despite the possible limitations of using a single nation and one financial year data, the results from this study provide an interesting and valuable insight about potential path for further in depth studies to complement on the ground knowledge to make the result more illuminating. Future studies on the current topic are therefore recommended. 


\section{References}

Abidin, Z. Z., Kamal, N. M., \& Jusoff, K. (2009). Board structure and corporate performance in Malaysia. International Journal of Economics and Finance, 1(1), 150-164.

ACA International. (2010). 2010 agency benchmarking survey. Retrieved from http://www.acainternational.org/files.aspx?p=/ images/12980/2010-benchmarking- survey.pdf

Angaye, P. E. G., Gwilliam, D., Marnet, O., \& Thomas, D. (2009). Board structure and value added performance in Nigeria. Economics, Finance and Accounting Applied Research. Working Paper Series, Coventry University Business School.

Bapepam and LK Rulebook. (2006). Ministry of Finance of the Republic of Indonesia: The Capital Market and Financial Institution Supervisory Agency. Duplicate of decision of the chairman of the Capital Market and Financial Institutions Supervisory Agency Number: KEP-134/BL/2006. Retrieved from http://www.bapepam.go.id/pasar_modal/regulasi_pm/ peraturan_pm/ENG/X/XK6.pdf

Bathula, H. (2008). Board characteristics and firm performance: Evidence from New Zealand. Unpublished doctoral dissertation. Auckland University of Technology, New Zealand.

Besar, D. S. (2012). Indonesian banking development: Financial services liberalization, the regulatory framework, and financial stability. Proceedings from Workshop on Trade in Financial Services and Development. June 2012, Geneva.

Bryan, L. L. (2007). The new metrics of corporate performance: Profit per employee. The McKinsey Quarterly, 1, 57-65.

Campbell, D., \& Abdul Rahman, M. R. (2010). A longitudinal examination of intellectual capital reporting in Marks \& Spencer annual reports, 1978-2008. The British Accounting Review, 42(1), 56-70.

Capital Market Supervisory Agency. (2004). Kep-29/PM/2004. Decision of chairman of Capital Market Supervisory Agency. Rule Number IX.I.5: Guidelines on establishment and working implementation of audit committee. Retrieved from http://www. bapepam.go.id/pasar_modal/regulasi_pm/peraturan_pm/ENG/IX/IXI5.pdf

Chan, Y. H. (2003). Biostatistics 101: Data presentation . Singapore Med J, 44(6), 280-285.

Chhinzer, N., \& Ghatehorde, G. (2009). Challenging relationships: HR metrics and organizational financial performance. The Journal of Business Inquiry, 8(1), 37-48.

Craig, E., Thomas, R. J., Hou, C., \& Mathur, S. (2011). No shortage of talent: How the global market is producing the STEM skills needed for growth. Accenture Institute for High Performance Research Report, September 2011.

D’ Amico, V. (2004). How technology can increase your revenue per employee. Damicon, LLC. Retrieved from http://www. damicon.com/resources/Revenue_Per_Employee.pdf

Dirks, S., Gurdgiev, C., \& Keeling, M. (2010). Smarter cities for smarter growth: How cities can optimize their systems for the talent-based economy. IBM Global Business Services Executive Report. USA: IBM Institute for Business Value.

Doucouliagos, H., Haman, J., \& Askary, S. (2007). Directors' remuneration and performance in Australian Banking. Corporate Governance: An International Review, 15(6), 1363-1383.

Ghosh, A., \& Aggarwal, R. (2011). Directors' remuneration: Various issues to firm performance. Paradigm, 15(1\&2), 93-102.

Groysberg, B. (2011). Talent in the financial institution. Harvard Business School Executive Education.

Gupta, V. (2000). Regression explained in simple terms. VJBook, Inc. Retrieved from https://www.google.com/\#q $=$ Regression+explained +++ Copyright $+\% \mathrm{C} 2 \%$ A $9+2000+$ Vijay + Gupta + Published + by + VJBooks + Inc.

International Monetary Fund. (2012). Indonesia: Financial Sector Assessment Program—Basel Core Principles Assessment—Detailed assessment of compliance. IMF Country Report, No. 12/335, December 2012.

Jakarta Stock Exchange Inc. (2004). Decision of the board of directors of the Jakarta Stock Exchange Inc.: Kep-305/BEJ/07-2004. Retrieved from http://www.idx.co.id/Portals/0 /StaticData/Regulation/ ListingRegulation/ en-US/I-A_Listing_ENG.pdf

Kelly Services, Inc. (2013). Kelly Services Indonesia 2013 Salary Guide. Retrieved from http://www.kellyservices.co.id/ uploadedFiles/indonesia_-_Kelly_Services/4-Resource_Centre/Salary_Guide/Indonesia\%20salary\%20guide\%20ebook.pdf

Kneer, C. (2013). The absorption of talent into finance: Evidence from U.S. banking deregulation. DNB Working Paper, No. 391, September 2013.

KPMG, LLP. (2010). New perspective on talent. Retrieved from https://www.kpmg.com/US/en/IssuesAndInsights/Articles Publications/Documents/new-perspectives-on-talent. pdf

Ljubojević, Č., \& Ljubojević, G. (2008). Building corporate reputation through corporate governance. Management, 3(3), 221-233.

Lublin, J. (2014). Smaller boards get bigger returns. Wall Street Journal. Retrieved from http://online.wsj.com/articles/ smaller-boards-get-bigger-returns-1409078628 
Mariner7.com. (n.d.). The business case for performance and talent management. Retrieved from https://mariner7.com $/ \mathrm{m} 7 \mathrm{home} /$ businesscase.pdf

Morgan Stanley. (2011). Global IT services "per-employee" metrics are key to quality of growth. Retrieved from http://www.morganstanleychina.com/conferences/ apsummit2011/research/30GlobalITServices.pdf

Nash, K. S. (2006, April). Topline 100 smartest companies. Baseline, April 2006, 17-22. Retrieved from http://www.strassmann. com/pubs/baseline/2006-4-a.pdf

National Committee on Governance. (2006). Indonesia's code of good corporate governance 2006. Retrieved from http://www. bapepam.go.id/pasar_modal/publikasi_pm/info_pm/Indonesia\%20Code\%20of\%20GCG\%202006.pdf

Oviantari, I. (2011). Directors and commissioners remuneration and firm performance: Indonesian evidence. Proceedings from the 2nd International Conference on Business and Economic Research. March 14-16, Langkawi, Kedah, Malaysia.

PwC. (2012a). Tackling the talent gaps-key findings in the financial services sector. PwC 15th Annual Global CEO Survey.

PwC. (2012b). Delivering results growth and value in a volatile world. 15th Annual Global CEO Survey 2012.

PwC. (2013). Indonesian banking survey 2013. Retrieved from http://www.pwc.com/id/en/publications/assets/pwc-indonesiabanking-survey-2013.pdf

Rebeiz, K. S., \& Salameh, Z. (2006). Relationship between governance structure and financial performance in construction. Journal of Management in Engineering, 22(1), 20-26.

Reeve, J. M., Warren, C. S., \& Duchac, J. E. (2012). Principles of accounting. 24th ed. USA: South-Western Cengage Learning.

Rouf, Md. A. (2011). The relationship between corporate governance and value of the firm in developing countries: Evidence from Bangladesh. The International Journal of Applied Economics and Finance, 5(3), 237-244.

Shapiro, J. M. (2006). Smart cities: Quality of life, productivity, and the growth effects of human capital. The Review of Economics and Statistics, 88(2), 324-335.

Society for Human Resource Management. (2012). 2012 employee benefits: The employee benefits landscape in a recovering economy. A research report by the Society for Human Resource Management. Retrieved from http://www.shrm.org/research/ surveyfindings/articles/documents/2012_empbenefits_report.pdf

Talha, M., Sallehhuddin, A., \& Masuod, Md. S. (2009). Corporate governance and directors' remuneration in selected ASEAN countries. The Journal of Applied Business Research, 25(2), 31-40.

Van Ness, R. K., Miesing, P., \& Kang, J. (2010). Board of director composition and financial performance in a sarbanes-oxley world. Academy of Business and Economics Journal, 10(5), 56-74.

Wallace, P., \& Zinkin, J. (2005). Mastering business in Asia: Corporate governance. Singapore: John Wiley \& Sons.

Yasmin, S., \& Yusuf, M. A. (2008). Market capitalization—concept, measurement and significance. The Cost and Management, March-April 2008, 27-33. 